\title{
Study on Equity Incentive of Listed Companies in China
}

\author{
Liu Menglu \\ School of business, Guizhou university of finance and \\ economics \\ Guiyang, China
}

\begin{abstract}
As an effective tool to solve the principal-agent problem, equity incentive is a long-term incentive way to stabilize the leadership team and key technical staffs. However, compared with the western countries, Chinese listed companies have different market conditions and institutional background for equity incentive. Thus there are still disputes in industry about option's effectiveness in public companies of China. And given the special background in China, it is significant to dialectically analyze the implementation of stock option incentive. This paper starts with the basic theory of equity incentive, analyzes the existing problems of equity incentive in China, and gives the corresponding solutions. Finally, by means of literature review and field research, this paper finds that listed companies in China are faced by the following problems: hitchhiking, fewer objects of equity incentive and incomplete assessment system. Then the paper offers the following solutions: optimize equity incentive design, define the scope of equity incentive objects, improve capital markets and strictly control the selection of company management.
\end{abstract}

Keywords-Equity incentive; Corporate governance; Problem; Methods

\section{INTRODUCTION}

Equity incentive originated in the United States in the 1950 s and 1960s, grew rapidly in the late 1990s, spread to the world, and reached its peak in the early 2000s. Through the organic combination of shareholders' interests and operators' interests, managers can take the overall interests of the enterprise as the pursuit goal, so as to reduce the principalagent cost, which is regarded as a good recipe to solve the principal-agent problem. However, with the disclosure of some well-known corporate scandals, the corporate governance model in developed countries has been questioned, especially the equity incentive. Most corporate governance models in China draw lessons from developed countries, so there are problems in China's equity incentive model. This paper starts from this, puts forward countermeasures, and hopes to contribute to the effective implementation of equity incentive mechanism in China's companies.

\author{
Liu Liangcan \\ School of business, Guizhou university of finance and \\ economics \\ Guiyang, China
}

\section{THEORETICAL BASIS OF EQUITY INCENTIVE}

\section{A. Basic Concept of Equity Incentive}

Equity refers to the rights and interests of Stockholders corresponding to the stocks they own and the right to assume certain responsibilities. Equity incentive is the equity in the form of shares granted by the owner of an enterprise to the operator so as to motivate the operator to do his best to help the shareholder to achieve the goal of wealth maximization. Its purpose is to enable the latter to proceed from the common interests of both sides, work hard, and ultimately achieve the maximum value of the entire enterprise. Its essence is a way to solve the principal-agent problem.

It is an effective long-term motivation. Equity incentive has four functions, that is, incentive function, constraint function, improving employee welfare function and stabilizing employee function.

\section{B. Basic mode of equity incentive}

\section{1) Performance stocks}

Performance stock refers to the determination of a reasonable performance goal at the beginning of the year. If the incentive object reaches the predetermined goal at the end of the year, the company grants a certain number of shares or extracts a certain reward fund to buy the shares of the company. The liquidity of performance stocks is usually limited by time and quantity. Another long-term incentive method similar to performance stock in operation and function is performance unit. The difference between performance stock and performance stock is that performance stock grants stock while performance unit grants cash.

\section{2) Stock options}

Stock option is a kind of right granted to the incentive object by the company. The incentive object can purchase a certain amount of the circulating stock of the company at a predetermined price within a specified period of time, or it can give up such right. The exercise of stock options is limited by time and quantity, and the incentive object should be cash for exercise. At present, the virtual stock option applied in some listed companies in China is the combination of virtual stock and stock option, that is, what the company grants the incentive object is a kind of virtual stock subscription right, and what the incentive object obtains after exercising the right is the virtual stock. 


\section{3) Virtual stock}

The company grants the incentive object a kind of virtual stock. The incentive object can enjoy a certain amount of dividend distribution right and stock price appreciation income according to this, but it has no ownership, no voting right, cannot be transferred and sold, and will automatically become invalid when leaving the enterprise. For example, what Huawei company grants its employees is virtual stock, and only dividends have no voting rights.

\section{4) Equity appreciation right}

Stock appreciation right means that if the stock price of the company rises, the incentive object can obtain the corresponding amount of stock price appreciation income through exercising the right. The incentive object does not pay cash for exercising the right, but obtains cash or equivalent company stock after exercising the right.

\section{5) Restricted stock}

Restricted stock grants a certain number of company stocks to incentive objects in advance, but there are some special restrictions on the source and selling of stocks. Generally, incentive objects can sell restricted stock and benefit from it only when the incentive objects achieve specific goals (such as turning a loss into a profit). Make a distinction here with achievement stock. Performance stock can only be acquired after certain performance is completed, while restricted stock has been acquired in advance. Only when the incentive object is required to achieve the corresponding goal, can it be sold for profit.

\section{6) Deferred payment}

Company as the object of incentive design package of salary income plan, which in some cases, equity incentive income equity incentive income is not the issue, but according to the company's stock fair market value conversion into shares, after a certain period, in the form of a company's stock or according to the value of the shares in cash to pay incentive object.

\section{7) Operator/employee stock ownership}

First of all, let the incentive object hold a certain number of shares of the company, which are donated by the company to the incentive object free of charge, or purchased by the company's subsidy to the incentive object, or purchased by the incentive object itself. The incentive object can benefit when the stock appreciates and lose when the stock depreciates.

\section{8) Management/employee acquisition}

The company's management or all employees use leverage financing to buy shares of the company, become shareholders of the company, share risks and benefits with other shareholders, so as to change the company's ownership structure, control structure and asset structure and realize shareholding operation.

\section{9) The right to increase the book value}

Specific cent is bought model and fictitious model two kinds. Purchase type refers to the incentive object actually buys a certain number of company shares at the beginning of the period according to the net asset value per share, and then sells back to the company at the end of the period according to the net asset value per share at the end of the period. Virtual type refers to that the incentive object does not need to spend capital at the beginning of the period, and the company grants a certain number of nominal shares to the incentive object. At the end of the period, the company calculates the income of the incentive object based on the increment of net assets per share and the number of nominal shares, and pays cash to the incentive object accordingly.

The above (1) - (8) are equity incentive models related to the securities market. In these incentive models, the earnings of the incentive object are affected by the stock price of the company. (9) is an equity incentive model unrelated to the securities market. The income of the incentive object is only related to one financial index of the company-with the relevant to net asset value per share, and has nothing to do with stock price.

\section{Design Factors of Equity Incentive}

(1) incentive objects: the incentive objects may include directors, senior management personnel, core technical personnel or core business personnel of the listed company, as well as other employees that the company believes should be stimulated that have a direct impact on the company's business performance and future development, but shall not include independent directors and supervisors. Foreign employees working in China who serve as directors, senior managers, core technical personnel or core business personnel of a listed company may be the objects of incentives.

(2) stock purchase provisions: that is, the relevant provisions on the purchase of equity by the incentive objects, including the purchase price, term, quantity and whether the stock purchase is allowed to be abandoned. The price that appear on the market buys a company commonly consult the stock market price that signs a contract at that time to decide, the price that other company buys a price to consult value of equity at that time to decide.

(3) provisions on share sales: that is, the relevant provisions on the selling of shares by the incentive objects, including the provisions on the selling price, quantity and term. Sale price is decided by the market value of the equity on the day of sale, the market price of the reference stock of the listed company among them, other company calculates sell price according to the method that decides beforehand commonly.

(4) rights and obligations: in equity incentive, it is necessary to stipulate whether the incentive object enjoys the right to dividends and gains, the right to vote on shares and how to bear the risk of equity depreciation.

(5) equity management: including the management mode, the source of equity access and the proportion of equity incentive in total revenue. The sources of equity acquisition include incentive object purchase, reward acquisition, technology investment, management investment and post investment. The effect of equity incentive varies with the proportion of the total income of the incentive object. 
(6) mode of operation: including whether the actual transfer relationship of the equity and the source of shares occur. In some cases, in order to avoid legal obstacles or other operational reasons, the actual equity transfer relationship does not actually occur in the equity incentive. In terms of equity sources, there are stock buybacks, secondary issuance of new shares, inventory shares and so on.

\section{EXISTING PROBLEMS OF EQUiTy INCENTIVE}

\section{A. Hitchhiking}

When some employees become partners, their motivation to work decreases rather than increases. When the number of incentives is too much, its partnership income (equity dividends, equity appreciation, etc.) accounts for too much, and its work income (as an employee's income - salary bonus, etc.) is ignored to a certain extent. At this time, the impact of hard work and leisure work on their income significantly reduced, it is easy to cause "minority shareholders do not work" situation.

The initial equity incentive must start from the core personnel, which is consistent with the strategic development of the company. Based on the business model of the company, rank, post and other relevant factors that can affect the performance of the organization are determined. Based on the relevant influencing factors, the equity incentive awarding standard is formulated and personnel are determined. In the later stage, due to the implementation of more extensive and hierarchical equity incentives, passive free riding may occur.

\section{B. Fewer Objects of Equity Incentive}

As mentioned above, the objects of equity incentive can be directors, senior managers, core technical personnel or core business personnel of listed companies, as well as other employees that the company believes should be encouraged that have a direct impact on the company's business performance and future development. However, most companies in China only choose senior executives or core employees as the incentive objects, and front-line employees are rarely taken as the incentive objects. In fact, for the strategic planning department, product design department and the positions requiring personal creativity, imagination and execution, equity incentives should be given to such employees in order to stimulate their enthusiasm for work and make them more diligent and responsible.

\section{Incomplete Assessment System}

The effective implementation of equity incentive mechanism depends on scientific evaluation system. Therefore, the implementation of the equity incentive system of listed companies in China urgently needs a set of perfect evaluation standard system to measure the management efficiency of operators and enterprise performance, and objectively and comprehensively explain the effectiveness and existing problems of the existing equity incentive system. At present, China's listed companies are still in a conservative state when establishing the index system, and the indicators are relatively single.
Most enterprises in China use financial indicators as assessment indicators, because the financial indicators are simple and intuitive, but the financial indicators have a great one-sidedness, can not fully reflect the business situation of enterprises, and are easy to be manipulated by managers, losing the objectivity and authenticity of their evaluation. Therefore, our country still needs to work hard on the appraisal system.

\section{SOLUTIONS}

\section{A. Optimize Equity Incentive Design}

To solve the problem of "free riding" and imperfect appraisal system, enterprises should optimize the design of equity incentive. Different equity incentive schemes have different influences on corporate performance, and different enterprises cannot copy the same scheme. Enterprises should choose appropriate equity incentive schemes according to their own situations, such as enterprise scale, development strategy and development stage. An incentive plan that is suitable for the actual situation of the enterprise, adapted to local conditions, and scientific and standardized is the necessary condition for its effective implementation.

At the same time, in terms of the design elements of the equity incentive scheme, it is necessary to take into account the actual situation of the company, seriously consider the object, method and quantity of the equity incentive scheme, and set the upper limit of the proportion of equity incentive to prevent managers from holding a high degree of shares.

\section{B. Define the Scope of Equity Incentive Objects}

The company can implement differentiated incentive mechanism according to the level of employees, and the incentive scheme can be more widely applied at all levels to promote the long-term healthy development of the company. Through the implementation of equity incentive system, the company's governance structure can be further improved. A scientific and reasonable equity incentive mechanism can prevent conflicts of interest between shareholders and operators, thus reduce agency costs to a certain extent, improve operators' subjective initiative and promote the healthy and stable development of enterprises.

\section{Improve Capital Markets}

First, all kinds of information related to the investors should be reliable and timely disclosure, thereby reducing because of the damage information transmission time intentionally hide, at the same time to effectively supervise agent decision-making and behavior, improve the operational efficiency of capital, speed up the flow rate of capital, to make more reasonable allocation of resources. Second, strengthen effective supervision. In the environment of "insider control", the government should change the way of administrative intervention to effectively supervise enterprises through market regulation, so as to achieve real reform of listed companies in China. 


\section{Strictly Control the Selection of Company Management}

Improve the manager market, evaluate the management level through a series of selection mechanisms so as to comprehensively assess the efforts of managers, and supervise and restrain the behavior and decision-making of the management level. The listed company selects the management layer in the talent market through the marketization standard, on the basis of speeding up the enterprise own reform, establishes a set of scientific personnel selection mechanism, pays attention to the human capital investment, abandons

the previous administrative appointment way. Through the selection of enterprise management by market method, equity incentive can effectively restrain the behavior of managers.

\section{CONCLUSION}

Practice has proved that as a way of enterprise management, equity incentive plays a good incentive role in supervising and restraining the behavior of enterprise management and encouraging agents to play a good role in the long-term development of enterprises and the improvement of enterprise value. However, not all enterprises are suitable for the operation and management mode of equity incentive. Therefore, when the company introduces equity incentive, it should study the applicable standards of equity incentive in depth, make emergency mechanism in case of special circumstances, and design the implementation plan of equity incentive scientifically. In the process of the implementation of equity incentive mechanism in our country, should first improve the capital market construction, establish and improve the company's management mechanism, according to the actual situation of the company to design a set of perfect management selection system and performance evaluation system, the various government departments should also strengthen the construction of legal system, the equity incentive mechanism can fully play a role in capital market.

\section{REFERENCES}

[1] Wu Na. Research on equity incentive of listed companies in China [J]. Knowledge economy, 2017,(7):96-97.

[2] Wang Yabo. Research on equity incentive of listed companies in China [J]. National circulation economy, 2017,(18):55-57.

[3] Chen Yanyan. Research on the implementation motivation and economic consequences of employee equity incentive [J]. Management review, 2015,(9):163-176.

[4] Yu Ying, tang Zongming, Chen Qiwei. Research on stock option incentive and China's system [J]. Economist, 2000, (6) : 68-73.

[5] Zhao Yiyuan. research on the applicability of stock options in listed companies in China $[\mathrm{J}]$. Journal of Nanjing university of science and technology, 2005, (12) : 36-39.

[6] Peng Si. Research on stock option system of Chinese listed companies after full circulation [J]. Sanjing observation, 2006 (8) : 137-138. 